\author{
В. Д. Дідух, Ю. А. Рудяк, А. Б. Горкуненко, І. П. Кузьмак, Л. В. Наумова \\ ДВНЗ “Тернопільський державний медичний університет імені І. Я. Горбачевського \\ МОЗ України”

\section{ІСТОРІЯ СТАНОВЛЕННЯ ТА РОЗВИТКУ МЕДИЧНОЇ ФІЗИКИ (ТЕПЛОТА, ЕЛЕКТРОМАГНЕТИЗМ) (ЧАСТИНА З)}

\author{
V. D. Didukh, Y. A. Rudyak, A. B. Horkunenko, I. P. Kuzmak, L. V. Naumova \\ I. Horbachevsky Ternopil State Medical University \\ THE HISTORY OF FORMATION AND DEVELOPMENT OF MEDICAL \\ PHYSICS (HEAT, ELECTROMAGNETISM) (PART 3)
}

\begin{abstract}
Мета роботи - висвітлити історичні шляхи розвитку медичної фізики, розкрити закономірності становлення і розвитку фундаментальних фізичних та медичних знань, їхній взаємозв’язок, показати їх еволюцію й значущість для минувшини та сьогодення.

Основна частина. У статті розглянуто деякі з етапів історії становлення та розвитку медичної фізики. Показано, як змінювалися наукові знання про теплові й електромагнітні явища упродовж сотень літ.

Стаття знайомить із деякими з тих, хто розширював межі людського знання про оточуючий світ, розкриваючи нові таємниці природи і її закони.

Дослідження теплових явищ привело до відкриття другого начала термодинаміки, яка займає особливе місце серед законів природи, а електромагнітних - до магнітних винаходів і впроваджень у медицині.

Саме знання історії розвитку науки не лише освітлює шляхи ії розвитку, а й сприяє її прогресу.

Висновок. У статті розглянуто етапи розвитку вчення про теплові та електромагнітні явища, становлення електрофізіології (електробіології) як науки.
\end{abstract}

Ключові слова: історія; медична фізика; становлення; розвиток.

The aim of the work - to highlight the historical ways of developing medical physics, to reveal the regularities of formation and development of fundamental physical and medical knowledge, their relationship, to show their evolution and significance for the past and present.

The main body. The article deals with some of the history stages of the formation and development of medical physics. It is shown how scientific knowledge about thermal and electromagnetic phenomena has changed during hundreds of years.

The article introduces some of those who expanded the boundaries of human knowledge about the surrounding world, revealing new secrets of nature and its laws.

The study of thermal phenomena led to the discovery of the second principle of thermodynamics, which occupies a special place among the laws of nature, and electromagnetic - to magnetic inventions and medical applications.

It is knowledge of the history of the development of science not only illuminates the ways of its development, but also contributes to its progress.

Conclusion. The article deals with the stages of development of the theory of thermal and electromagnetic phenomena, the formation of electrophysiology (electrical biology) as a science.

Key words: history; medical physics; becoming; development.

Вступ. Витоки досліджень теплових явищ сягають античних часів. Проте наукове вивчення теплових явищ почалося лише з XVIII ст. після винайдення Галілеєм термометра (термоскопа), який складався зі скляної трубки, один кінець якої закінчувався кулькою. Відкритий кінець трубки опускали в посудину з водою, яка заповнювала частину трубки. Коли повітря в кульці нагрівалося чи охолоджувалося, рівень води у трубці, відповідно, опускався чи піднімався.

( В. Д. Дідух, Ю. А. Рудяк, А. Б. Горкуненко та ін.
У 1840-1841 рр. німецький вчений, доктор медицини Юліус Роберт фон Маєр (1814-1878) (рис. 1), який брав участь у плаванні на острів Ява на посаді корабельного лікаря, помітив, що колір венозної крові матросів у тропіках значно світліший, ніж у північних широтах. Він встановив, що кількість окислюваних продуктів в організмі людини зростає із збільшенням роботи, яку вона виконує. Все це дало Маєру підстави вважати, що теплота і механічна робота здатні взаємно перетворюватися. За його розрахунком, нагрівання 1 кг води на $1^{0}$ 
еквівалентне роботі по підйому 1 кг вантажу на 365 м. У своїх працях 1841-1845 рр. він сформулював закон збереження і перетворення енергії: “При всіх фізичних і хімічних процесах дана сила залишається постійною величиною” [1]. Під силою ми розуміємо енергію.

У 1843 р. еквівалентність між виконаною роботою і теплотою встановив Джеймс Джоуль. Він дослідив, що 1 ккал еквівалентна 460 кгс·м.

Славетний фізик Іван Пулюй винайшов прилад для визначення значення механічного еквівалента теплоти, який у 1878 р. на Всесвітній виставці у Парижі був відзначений срібною медаллю [2]. Пулюй встановив, що значення механічного еквівалента теплоти лежить у межах 425,2 кгс.м до 426,6 кгс•м, що дуже близьке до його сучасного значення - 427 кгс $\cdot$ м.

Мета роботи - висвітлити історичні шляхи розвитку медичної фізики, розкрити закономірності становлення і розвитку фундаментальних фізичних та медичних знань, їхній взаємозв’язок, показати їх еволюцію й значущість для минувшини та сьогодення.

\section{Основна частина.}

\section{Теплота}

Визначний німецький природознавець Герман Гельмгольц (рис. 2) - професор фізіології Кенігсберзького, Боннського, Гейдельберзького університетів (1849-1871), професор фізики Берлінського університету і з 1888 р. директор Фізико-технічного інституту, у праці “Про збереження сили” обгрунтував закон збереження енергії (сили) і надав закону математичного виразу.

Згодом стало відомо, що цей закон вперше відкрив французький фізик та інженер Саді Карно у 1824 р. (рис. 3), який він сформулював у своїй праці "Роздуми про рушійну силу вогню і про машини, здатні розвивати цю силу”: “Тепло є нічого більше, як рушійна сила чи, вірніше, рух, який змінив свій

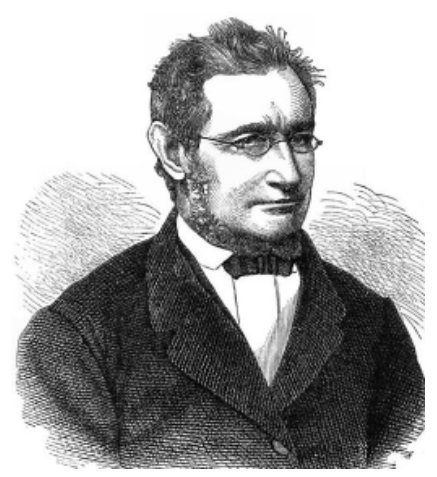

Рис. 1. Юліус Роберт фон Маєр.

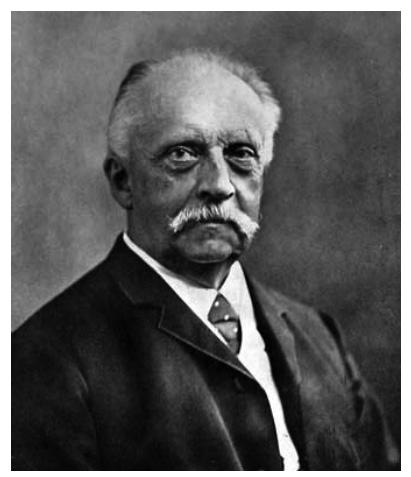

Рис. 2. Герман Гельмгольц.

вигляд; це рух частинок тіла; повсюди, де відбувається знищення рушійної сили, виникає одночасно теплота у кількості, точно пропорційній кількості знищеної рушійної сили. I навпаки: завжди при зникненні тепла виникає рушійна сила” [3]. Подальші дослідження показали, що лише кінетична теорія може пояснити теплові явища і кількісні закономірності.

У рівноважній термодинаміці закон збереження енергії формулюється так: при будь-яких процесах в ізольованій системі внутрішня енергія системи $U$ залишається сталою:

$$
U=\text { const, } d U=0 .
$$

У замкнутій термодинамічній системі приріст її внутрішньої енергії при зміні стану рівний сумі кількості теплоти, переданої системі, і роботи зовнішніх сил над системою:

$$
d U=\delta Q+\delta A .
$$

K. Тімірязєв на основі закону збереження енергії встановив (1875) кількісну залежність між швидкістю фотосинтезу і вбиранням хлорофілом світлових хвиль різної довжини.

\section{Електромагнетизм}

Із сивої давнини до нас доходять відомості про лікувальні властивості магнітів. Кожен відомий лікар минулого пропонував власний рецепт використання магнітів. Вважалося, що магніт відтягує грижу, знімає переломи, витягує жовтуху і водянку, заспокоює болі різного походження, заліковує рани, відновлює порушену чутливість шкіри.

На дивні властивості знаменитого магнітного залізняка (направляючого каменя чи компаса) першими звернули увагу греки близько 800 р. до н. е. Фалес, а пізніше Анаксагор та інші приписували йому божественне начало і вважали, що у магнітного залізняка є душа. Ось як високохудожньо описав його властивості у своїй поемі “Про природу речей” славетний римський поет Тіт Лукрецій Кар (95 р. до н. е. -51 р. н. е.) (рис. 4):

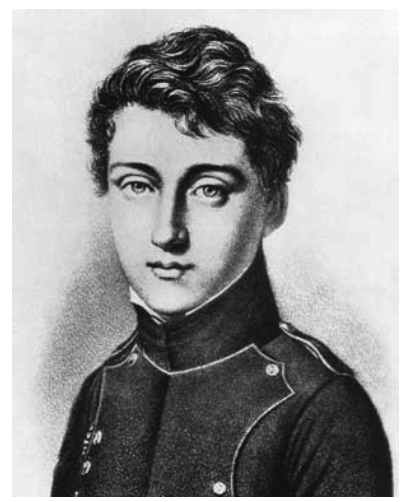

Рис. 3. Саді Карно.

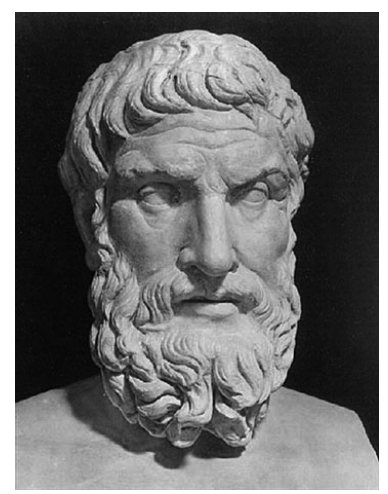

Рис. 4. Тіт Лукрецій Кар. 
“Врешті, ще й те поясню, за яким це законом природи

Може залізо до себе притягувати той знаменитий Камінь, що греки магнітом його недарма йменували,

Бо, як гадають, походить він з вітчизни магнетів. Камінь той справді дивує людей: він утворює часто

Наче ланцюг, що висить, хоч нескріплений, ланка при ланці.

Бачити можна не раз, як тих каменів п’ять, а то й більше,

Так, ніби в низці, висять, ще й на вітрі гойдаються легко.

Знизу один із них липне до кожного; кожен черпає Силу в сусіднього, зверху, щоб нижньому тут же подати...” [4].

Перше грунтовне експериментальне дослідження електричних і магнітних явищ належить англійському лейб-медику королеви Єлизавети Вільяму Гільберту (1544-1603) (рис. 5).

Теорія магнітних полів Гільберта сформульована таким чином: “Магнітні промені поширюються у всіх напрямках у сфері; центр цієї сфери знаходиться не на полюсі, а в центрі каменя”. Гільберт першим здійснив намагнічення тіла, встановив факт невіддільності магнітних полюсів, помітив відмінність електричних і магнітних явищ: “Магнетизм, так як і вага, є деякою початковою силою, яка виходить із тіл, тоді як електризація обумовлена витискуванням із пор тіла особливих витоків у результаті тертя”. Саме Гільберт довів, що Земля являє собою магніт. Він же висловив припущення про рефлекторний принцип роботи центральної нервової системи. Головне його відкриття у фізіології - схема безумовного рефлексу на основі вивчення мигання ока при доторкуванні до рогівки.

В основі лікувальної дії магнітного поля лежить використання його біофізичних ефектів. Магнітне поле змінює напрямок руху заряджених частинок у біологічних середовищах, відновлює поляризацію молекул, структурує вільні молекули води. Завдяки цьому також стимулюються процеси відновлення, загоєння і реабілітації різних тканинних пошкоджень.

Досліджував явище магнетизму і славетний Галілео Галілей (рис. 6). Він проводив різноманітні досліди з магнітом і металами, вважаючи, що субстанція магніта відрізняється від заліза.

Саме від Галілея бере початок фізика як наука. Завдяки Галілею лінзи і прилади стали могутнім

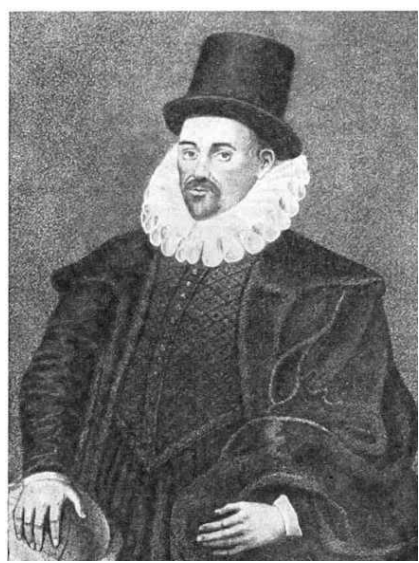

Рис. 5. Вільям Гільберт.

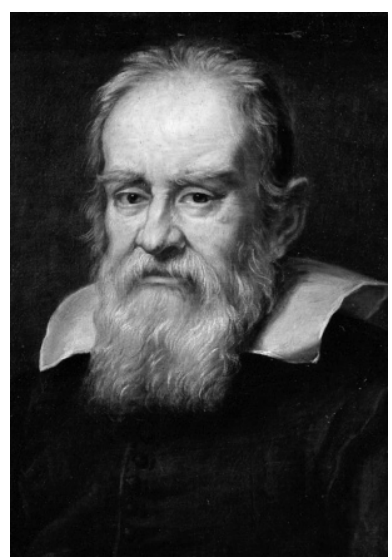

Рис. 6. Галілео Галілей. знаряддям наукових досліджень, за допомогою яких він побудував підзорну трубу, відкрив гори на Місяці, чотири супутники Юпітера, відкрив фази у Венери, плями на Сонці, довів що Молочний (Чумацький) шлях складається із незчисленної кількості зірок. Дослідження Галілея утвердили геліоцентричну систему світу, зі всією очевидністю переконали у справедливості учення Коперніка i хибності системи Арістотеля і Птолемея.

Магдебурзький бургомістр і фізик Отто фон Геріке (1602-1686) у 1662 р. винайшов перший пристрій для одержання статичної електрики (рис. 7,8$)$.

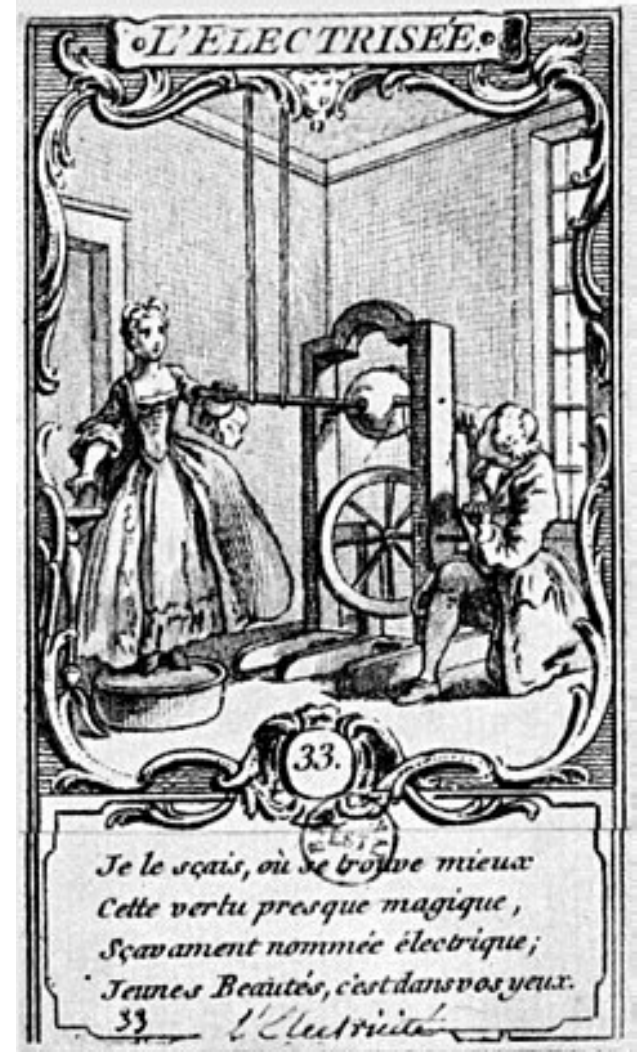

Рис. 7. Пристрій для одержання статичної електрики. Гравюра 1750 р. 


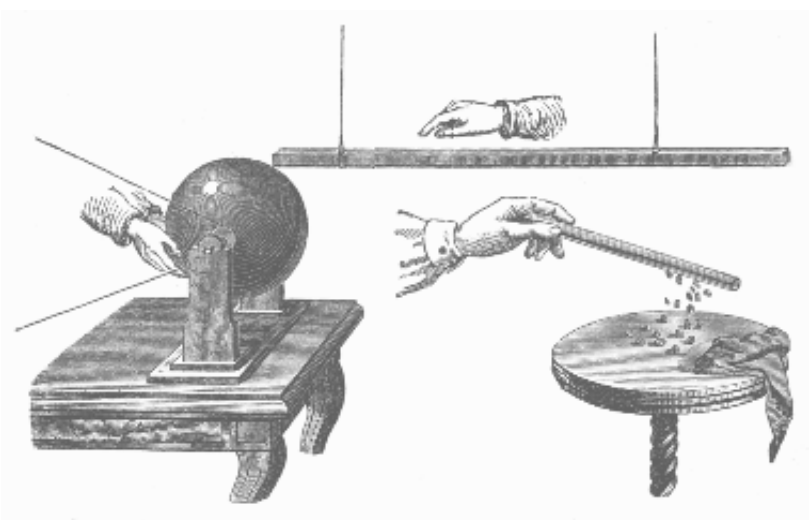

Рис. 8. Конструкція пристрою, описана у праці “Нові, так звані магдебурзькі, досліди про порожній простір” (1672).

Пристрій складався з великої сірчаної кулі, насадженої на вісь. Цю кулю обертали і натирали сухими руками. Наелектризувавши її, Геріке відзначив, що тіла притягуються кулею, а після дотику відштовхуються від неї, а тоді притягуються іншими тілами [5]. У 1662 р. ним було помічено, що наелектризована сірчана куля світиться в темноті. Так було відкрите явище електролюмінесценції.

У 1787 р. англійський фізик і лікар Адамс створив електростатичну машину і запропонував її використовувати з лікувальною метою. Інтерес до її застосування зростав, і Руанська (Німеччина) академія оголосила конкурс на роботу за темою “Визначити ступінь і умови, при яких можна розраховувати на електрику у лікуванні хвороб”. Перша премія була присуджена Марату - лікарю, політичному діячу часів французької революції [6]. Початок застосування статичної електрики 3 лікувальною метою (метод франклінізації) датується XVIII ст. Людина, стоячи на ізольованій підставці, перебувала в електростатичному полі. Один із лікувальних ефектів зумовлений поляризацією як окремих молекул клітин і тканин, так і викликаний індукованими на поверхні тіла електричними зарядами, а в провідній системі - мікрострумів. Було досліджено, що електростатичне поле порядку 10 кВ/м може викликати поділ хромосом.

1786 рік залишив яскравий слід в історії медицини і фізики, зокрема завдяки італійському вченому Луїджі Гальвані (1733-1798) (рис. 9). Він у 1759 р. закінчив Болонський університет за спеціальністю “Богослов’я”, та після захисту дисертації, під впливом свого тестя - професора медицини Карло Галеацці, почав займатися медициною. Після захисту магістерської дисертації, яка була присвячена будові людських кісток, Гальвані у 1762 р. почав

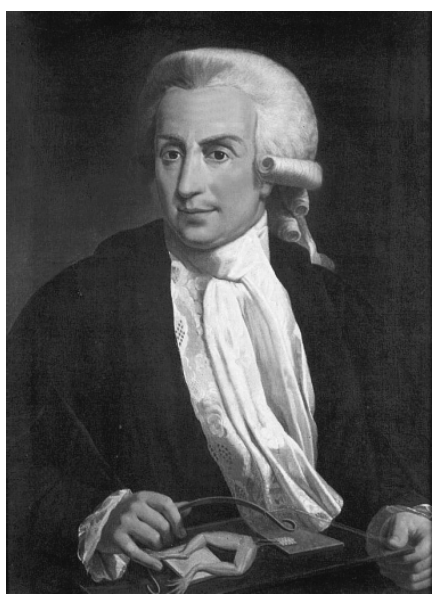

Рис. 9. Луїджі Гальвані.

викладати медицину. 1763 р. він став професором університету, а з 1785 р. - завідувачем кафедри анатомії та гінекології. За те, що він відмовився скласти присягу Цизальпінській республіці, яку заснував Наполеон Бонапарт у 1797 р., Гальвані був звільнений з роботи.

Ось як описує своє відкриття Луїджі Гальвані у “Трактаті про сили електрики при м’язовому русі”: “Я розрізав і препаруваву жабу... i, маючи на увазі зовсім інше, помістив її на стіл, на якому стояла електрична машина... при повному від’єднанні від кондуктора машини останньої і на великій відстані від нього. Коли ж один із моїх помічників вістрям скальпеля випадково доторкнувся внутрішніх стегнових нервів цієї жаби, то відразу всі м’язи кінцівок почали так скорочуватися, що здавалися запалими в найсильніші тонічні судоми. Інший же з них, який нам допомагав у дослідах з електрики, помітив, як йому здалося, що це відбувається тоді, коли із кондуктора машини виходила іскра. Вражений новим явищем, він відразу звернув на нього мою увагу, хоча я задумував зовсім інше і був зайнятий своїми думками. Тоді я запалився неймовірним зусиллям і палким бажанням дослідити це явище і винести на світ те, що було у ньому прихованого” (рис. 10).

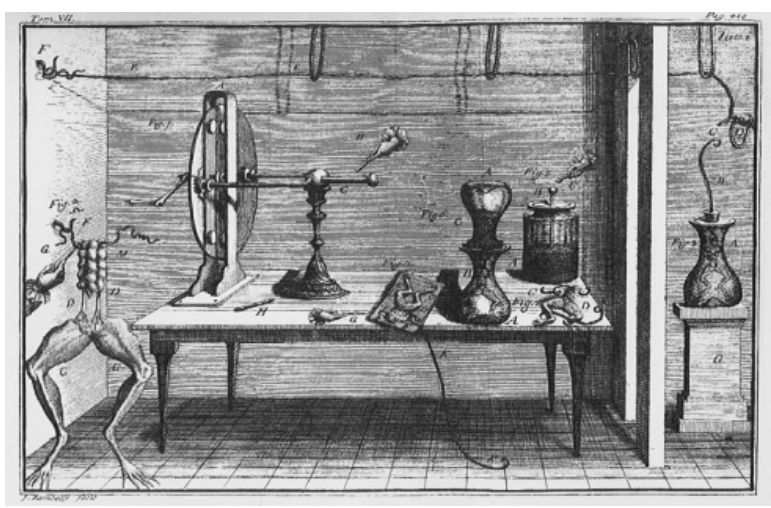

Рис. 10. Дослід Гальвані. 
Знаючи, що лапка жабки у певному розумінні $\epsilon$ дуже чутливим електрометром, Гальвані спробував виявити атмосферну електрику. Він підвісив на балконі препаровану жабу, вставивши їй мідний гачок у спинний мозок. I коли одного дня лапка жаби своїм звисаючим кінцем доторкнулася залізної решітки, то скоротилася. Це сталося 26 вересня 1786 р. I цю дату вважають днем народження електрофізіології (електробіології).

У цей же час італійський фізик Алессандро Вольта (іменем якого названа одиниця напруги) (рис. 11), винахідник чутливого електроскопа, конденсатора, перевірив результати Гальвані й переконався в тому, що найсильніше скорочення лапки жаби відбувається тоді, коли зовнішнім провідником замикаються дві різні ділянки добре відпрепарованого нерва. Вольта зробив висновок, що не м'яз розряджається через провідник і нерв, а навпаки, нерв, який більш чутливий до подразнення, збуджується і щось передає м'язу. Вольта після численних експериментів переконався у тому, що контакт двох різнойменних металів $\epsilon$ новим джерелом електрики, на яку реагує живий “електроскоп” - препарована жаба. Він показав, що два різнойменні метали діють на препарат жаби тим сильніше, чим далі стоять вони у наступному ряду: цинк, олово, свинець, залізо, латунь, бронза, мідь, платина, золото, срібло, ртуть, графіт, вугілля. Гальвані ж, відстоюючи свою теорію про тваринну електрику, впродовж 1794-1797 рр. провів нові досліди, у яких вже не використовув метали. Розглянемо один із них. Гальвані брав м’яз із відгалуженим від нього нервом (рис. 12). Віддалений кінець нерва перерізав і за допомогою скляної палички торкався ним м'яза. У момент доторкуван-

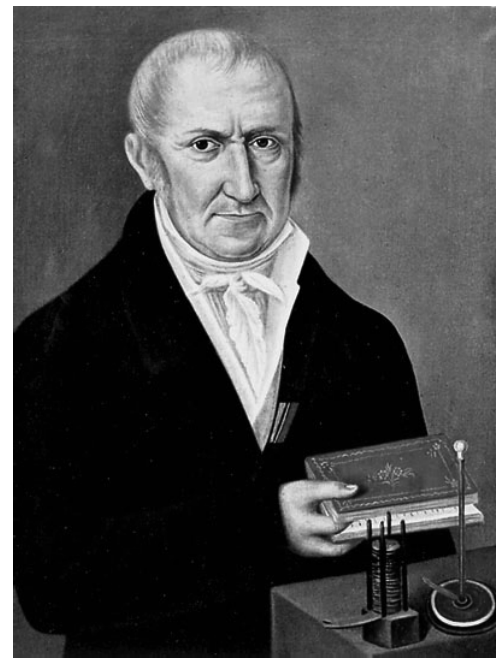

Рис. 11. Алессандро Вольта. ня нерва до м'яза останній скорочувався. Гальвані вважав, що місце перерізу, очевидно, відіграє якусь важливу роль.

На жаль, цей та інші досліди Гальвані не зміг опублікувати - вони були описані лише у приватних листах [7].

В історичній суперечці обидва вчені мали рацію, кожен із них був по-своєму правий. Гальвані відкрив два різних явища - i “тваринну електрику”, і електрику, спричинену різними металами. Проте він сам вважав, що відкрив лише перше із них, а Вольта був переконаний, що джерелом електрики в дослідах Гальвані був не м'яз жаби, а ті два метали, якими до неї доторкувався Гальвані.

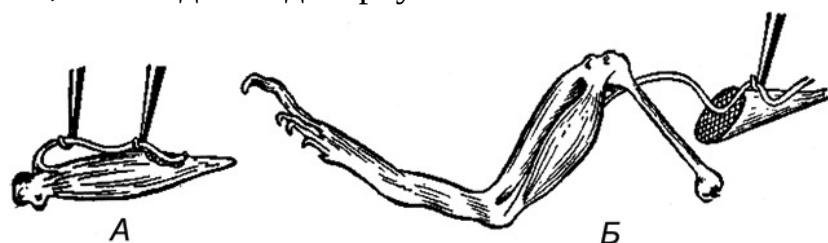

Рис. 12. Способи накладання нерва.

Гальвані увійшов в історію науки як основоположник електрофізіології (електробіології), а фізик Вольта - як винахідник першого хімічного джерела гальванічного (електричного) струму.

Винайдення Вольтою гальванічної батареї, яка складалася з багатьох послідовно з'єднаних цинкових і мідних пластин, опущених попарно в посудини із розведеною кислотою, стало початком нових відкриттів у різних галузях науки (рис. 13).

Вольта демонструє дію створеної ним гальванічної батареї Першому консулу Франції- майбутньому імператору Наполеону Бонапарту [8].

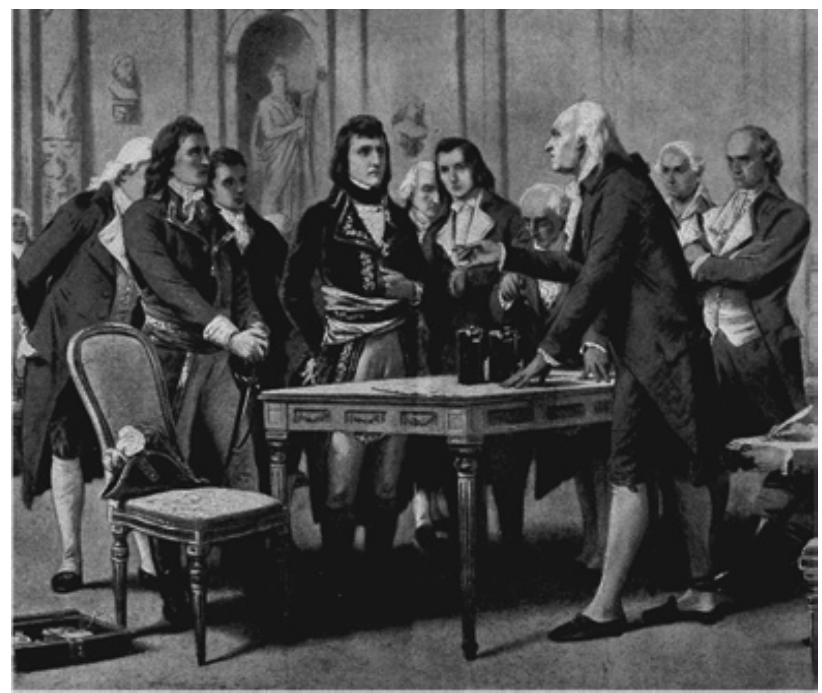

Рис. 13. Демонстрація гальванічної батареї. 
Професор фізики медико-хірургічної академії у Санкт-Петербурзі В. Петров (1761-1834) вивчав можливості електролікування, створив електричну батарею із 4200 мідних і цинкових елементів, першим у світі винайшов електричну дугу (1802), хоча пріоритет винаходу приписали англійському досліднику X. Деві, який спостерігав це явище у 1808 р. Створена В. Петровим електрофізична лабораторія дозволила вченим широко розгорнути дослідження у сфері застосування електростатичних полів для лікування.

На честь Бенджаміна Франкліна (1706-1790) (рис. 14) - одного із засновників США, політичного діяча, дипломата, вченого, письменника, журналіста, який пояснив принцип дії лейденської банки, побудував перший плоский конденсатор, довів у 1747 р. електричну природу блискавки, винайшов блискавковідвід, встановив тотожність атмосферної і отриманої за допомогою тертя електрики (1752) - був названий метод електротерапії постійним струмом високої напруги - франклінізація.

Максвелл Джеймс Клерк у 1860-1865 рр. сформулював теорію електромагнітного поля у вигляді рівнянь, які виражають основні закономірності електромагнітних явищ, і передбачив існування у вільному просторі електромагнітних хвиль, які поширюються у ньому зі швидкістю світла (рис. 15).

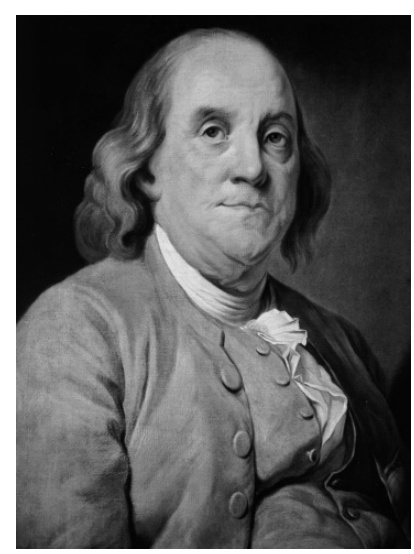

Рис. 14. Бенджамін Франклін.

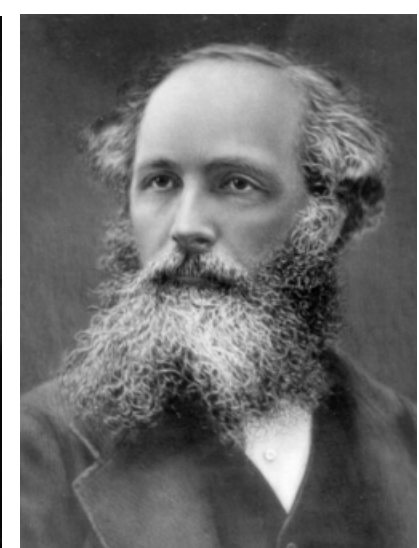

Рис. 15. Максвелл Джеймс Клерк.
Рівняння Максвелла показують, що джерелами електричного поля можуть бути або електричні заряди, або магнітні поля, які змінюються в часі. Магнітні ж поля можуть збуджуватись або рухомими зарядами (електричними струмами), або змінними електричними полями.

Основоположник фізіотерапії, французький фізик і фізіолог Жак Д’Арсонваль (1851-1940) (рис. 16), член Паризької АН (з 1894 р., а в 1917 р. - президент), винайшов магнітний телефон, прилад для вимірювання постійного електричного струму, аперіодичний гальванометр (1886), в якому вимірюваний струм проходить через легку рухливу катушку, поміщену у магнітне поле (гальванометр Д’Арсонваля). Він проводив дослідження, застосовуючи струми високої частоти, і в 1891 р. запропонував метод електролікування, названий дарсонвалізацією.

У 1837 р. італійський учений Маттеучі, використовуючи чутливий гальванометр, показав, що при збудженні непошкодженого м'яза між його частинами протікає струм, який може збуджувати нерв, що лежить на м’язі.

Дослідження Маттеучі переконливо довели, що процеси збудження пов'язані з електричними явищами.

На зв' язок між електрикою і магнетизмом вказав геніальний Майкл Фарадей (рис. 17). У 1831 р. він зробив велике відкриття - явище електромагнітної індукції. На залізне кільце він намотував дві окремі спіралі, одна з яких була з'єднана з батареєю, а інша - з гальванометром. При замиканні першого кола спостерігалося різке відхилення стрілки гальванометра, а при розмиканні кола - відхилення її у протилежний бік.

Максвелл писав: “Приступивши до вивчення праці Фарадея, я встановив, що його метод розуміння явищ був також математичним, хоча і не був представлений у формі звичайних математичних символів. Я також знайшов, що цей метод можна виразити у звичайній математичній формі, і таким чином порівняти з методами професійних математиків. Так, наприклад, Фарадей бачив силові лінії, які пронизують простір, там, де математики бачили центри сил, які притягують на відстані, Фарадей бачив середовище там, де вони не бачили нічого, крім відстані. Фарадей передбачав джерело і причину явищ у реальних діях, які відбуваються в середовищі, вони ж були задоволені тим, що знайшли їх в силі дії на відстані, яку віднесли до електричних флюїдів” [9]. Користуючись вібратором і резонатором, Генріх Герц у 1888 р. (рис. 18) експериментально довів існування електромагнітних хвиль, передбачених теорією Максвелла, які займають особливе місце серед різноманітних методів діагностики та лікування.

Вібратор Герца складався з двох прямолінійних провідників, на кінцях яких знаходилися металеві кондуктори сигароподібної форми. На других кінцях цих провідників знаходилися маленькі мета- 


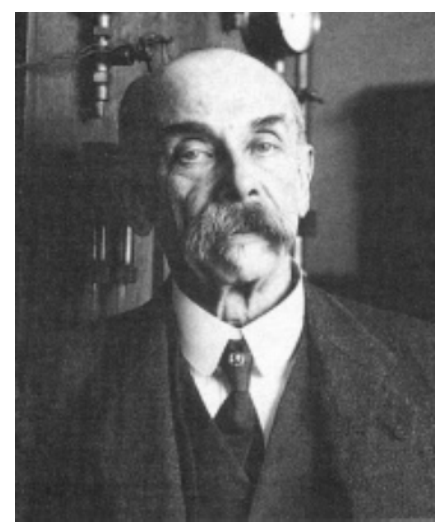

Рис. 16. Жак Д’Арсонваль.

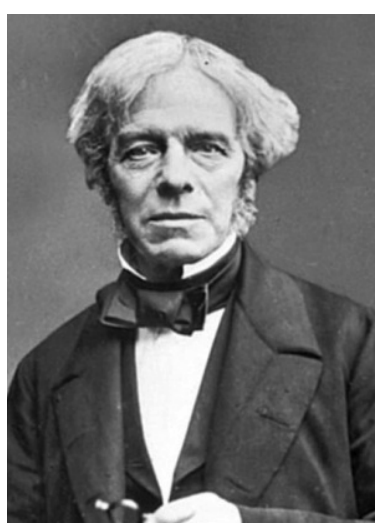

Рис. 17. Майкл Фарадей.

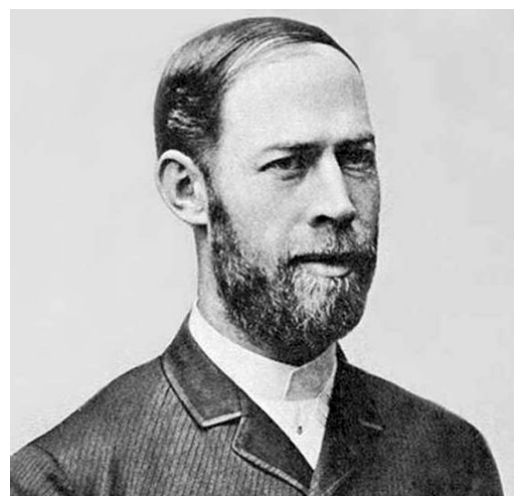

Рис. 18. Генріх Герц.

леві кульки, які утворювали іскровий проміжок $B$. Обидва провідники з’єднувалися з кінцями однієї 3 обмоток індукційної котушки А. При проскакуванні іскри в іскровому проміжку $B$ провідники випромінювали електромагнітні коливання, які фіксував резонатор - рамка зі сторонами $a c d b$ і в проміжку М виникали іскри (рис. 19) [10].

Англійський фізіолог Огюст Уоллер (1856-1922) (рис. 20) одним із перших записав (1887) електрокардіограму людини. Він запропонував розглядати серце як електричний диполь і запропонував концепцію електрокардіограми, яку послідовно розробив у ХX ст. лауреат Нобелівської премії (1934) Віллем Ейнтховен (1860-1927) (рис. 21).

\section{Список літератури}

1. Волькенштейн М. В. Энтропия и информация / М. В. Волькенштейн. - М. : Наука, 1986. - С. 24.

2. Шендоровський В. До 100-річчя від дня смерті Івана Пулюя / В. Шендоровський // Світогляд. - 2018. № 1 (69). - С. 48.

3. Волькенштейн М. В. Энтропия и информация/ М. В. Волькенштейн. - М. : Наука, 1986. - С. 25-26.

4. Тіт Лукрецій Кар. Про природу речей / Тіт Лукрецій Кар. - К. : Дніпро, 1988. - С. 169.
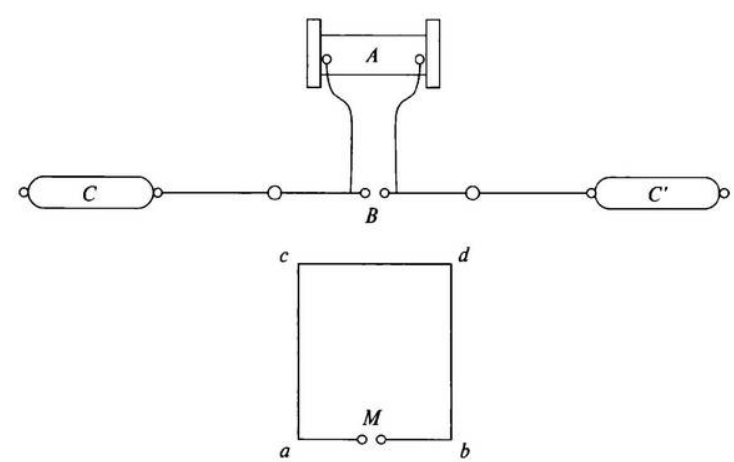

Рис. 19. Вібратор і резонатор Герца.

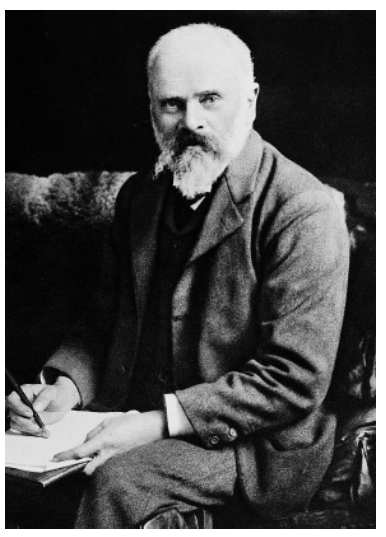

Рис. 20. Огюст Уоллер.

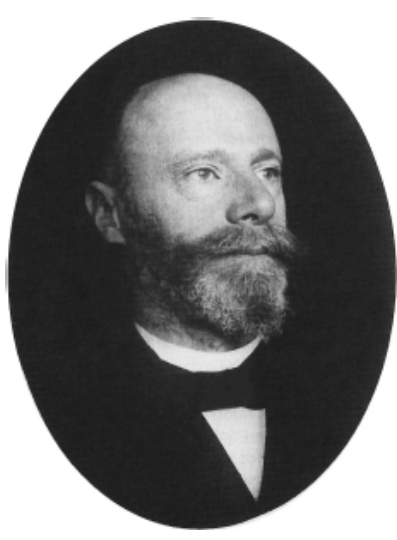

Рис. 21. Віллем

Ейнтховен.
Біопотенціали, які виникають в органах і тканинах живого організму, надзвичайно чутливо відображають його функціональний стан. Томуто аналіз зареєстрованих біопотенціалів знайшов широке застосування у медичній практиці. Особливого поширення набув метод електрокардіографії - дослідження функціонального стану серця, його автоматизму, збудливості й провідності шляхом графічної реєстрації зміни електричних потенціалів, які виникають у серцевому м'язі в процесі його збудження.

Висновок. У статті розглянуті етапи розвитку вчення про теплові та електромагнітні явища, становлення електрофізіології (електробіології) як науки.

5. Спасский Б. И. История физики / Б. И. Спасский. М. : Высшая школа, 1977. - С. 170.

6. Манойлов В. Е. Электричество и человек / В. Е. Манойлов. - Ленинград : Энергоатомиздат, 1983. - С. 73-74.

7. Дідух В. Д. До історії започаткування електрофізіології (електробіології) / В. Д. Дідух, С. Н. Вадзюк, О. Л. Михалюк // Тернопільські біологічні читання 2017. - Тернопіль : Terno-graph, 2017. - С. 353-356. 
8. Энергетика. История и опыт - путь к современной энергетике / С. Г. Плачкова, И. В. Плачков, В. С. Дунаевская [и др.]. - с: \users\admunustrator\ Desktop\6.1. Открытие гальванического тока - Энергетика_история, настоящее и будущее. htmlı.

\section{References}

1. Volkenshtein, M.V. (1986). Entropiya i informatsiya [Entropy and information]. Moscow: Nauka [in Russian].

2. Shendorovskyyi, V. (2018). Do 100-richchia vid dnia smerti Ivana Puliuia. [To 100-year anniversary from the day of the death of Ivan Pului]. Svitohliad - Worldview, 1 (69) [in Ukrainian].

3. Volkenshteyn, M.V. (1986). Entropiya i informatsiya [Entropy and information]. Moscow: Nauka [in Russian].

4. TIt Lukretsii Kar (1988). Pro pryrodu rechei [About the nature of things]. Kyiv: Dnipro [in Ukrainian].

5. Spasskiy, B.I. (1977). Istoriya fiziki [History of physics]. Moscow: Vysshaya shkola [in Russian].

6. Manoylov, V.E. (1983). Elektrichestvo i chelovek [Electricity and human]. Leningrad: Energoatomizdat [in Russian].
9. Кравец Т. П. М. Фарадей и его “Экспериментальные исследования по электричеству” / Т. П. Кравец. - 1947. Т. 1. - С. 744.

10. Кудрявцев П. С. Курс истории физики / П. С. Кудрявцев. - М. : Просвещение, 1982. - С. 256.

7. Didukh, V.D., Vadziuk, S.N., \& Mykhaliuk, O.L. (2017). Do istorii zapochatkuvannia elektrofiziologii (elektrobiolohii) [To the history of electrophysiology (electrobiology) introduction.] Ternopilski biolohichni chytannia - Ternopil Biological Readings, 353-356 [in Ukrainian].

8. Plachkova, S.G., Plachkov, I.V., \& Dunayevskaya, V.S. Energetika. Istoriya i opyt - put $k$ sovremennoy energetike [Energetics. History and experience - the path to modern energetics]. Retrieved from: http://energetika.in.ua/ru/ books/book-2 [in Russian].

9. Kravets, T.P., \& Faradey, M. (1947). Eksperimentalnye issledovaniya po elektrichestvu [Experimental studies on electricity]. Moscow: Izdatelstvo Akademii Nauk SSSR [in Russian].

10. Kudryavtsev, P.S. (1982). Kurs istorii fiziki [Physics history course]. Moscow: Prosveshchenie [in Russian].

Отримано 10.10.18

Електронна адреса для листування: horkunenkoab@tdmu.edu.ua 